\title{
Perceived thickness and creaminess modulates the short-term satiating effects of high-protein drinks
}

\author{
Emma J. Bertenshaw ${ }^{1}$, Anne Lluch $^{2}$ and Martin R. Yeomans ${ }^{1 *}$ \\ ${ }^{1}$ School of Psychology, University of Sussex, Brighton BN1 9QH, UK \\ ${ }^{2}$ Global Nutrition Department, Danone Research, RD 128, 91767, Palaiseau, France \\ (Submitted 10 April 2012 - Final revision received 1 October 2012 - Accepted 2 November 2012 - First published online 14 January 2013)
}

\begin{abstract}
Previous research suggests that increasing beverage protein content enhances subsequent satiety, but whether this effect is entirely attributable to post-ingestive effects of protein or is partly caused by the distinct sensory characteristics imparted by the presence of protein remains unclear. To try and discriminate nutritive from sensory effects of added protein, we contrasted effects of three higher-energy (about $1.2 \mathrm{MJ}$ ) and one lower-energy (LE: $0.35 \mathrm{MJ}$ ) drink preloads on subsequent appetite and lunch intake. Two higher-energy drinks had $44 \%$ of energy from protein, one with the sensory characteristics of a juice drink (HP-, low-sensory protein) and the second a thicker and creamier (HP+, high-sensory protein) drink. The high-carbohydrate preload (HC+, high-sensory carbohydrate) was matched for thickness and creaminess to the HP+ drink. Participants (healthy male volunteers, $n$ 26) consumed significantly less at lunch after the $\mathrm{HP}+(566 \mathrm{~g})$ and $\mathrm{HC}+(572 \mathrm{~g})$ than after $\mathrm{HP}-(623 \mathrm{~g})$ and $\mathrm{LE}(668 \mathrm{~g})$ drinks, although the compensation for drink energy accounted for only $50 \%$ of extra energy at best. Appetite ratings indicated that participants felt significantly less hungry and more full immediately before lunch in HP+ and HC+ groups compared with LE, with HP- being intermediate. The finding that protein generated stronger satiety in the context of a thicker creamier drink ( $\mathrm{HP}+$ but not $\mathrm{HP}-$ ) and that an isoenergetic carbohydrate drink (HC+), matched in thickness and creaminess to the HP+ drink, generated the same pattern of satiety as HP+, both suggest an important role for these sensory cues in the development of protein-based satiety.
\end{abstract}

Key words: Protein: Satiety: Viscosity: Thickness

It has been widely reported that meals with a higher proportion of energy as protein are more satiating than isoenergetic meals lower in protein content, both in acute tests of satiety using short-term measures of rated appetite and/or intake $^{(1-10)}$ and longer-term studies on manipulated protein content of the diet ${ }^{(11-14)}$. However, there remains some uncertainty about the mechanisms underlying the enhanced satiating efficiency of protein-based foods and drinks. Although there is clear evidence that protein ingestion results in a different profile of satiety-related hormonal signals compared with other macronutrients ${ }^{(15-17)}$ that have been interpreted as the basis of protein-based satiety ${ }^{(18)}$, a confounding issue in interpretation of many short-term studies of protein-based satiety is the difficulty in fully disguising the addition of protein. This often results in orosensory differences between protein and control conditions, which could also contribute to the behavioural effects of these foods and drinks. It is well established that orosensory cues are an important component of short-term satiety. For example, high-energy preloads have been shown to be more satiating when ingested by the participant than when infused directly into the stomach or intestine ${ }^{(19)}$. Observations like this add weight to the satiety-cascade model ${ }^{(20)}$, where learned and sensory cues from food are suggested to be critical components of the shortterm satiating effects of nutrients. Several recent studies provide additional evidence to support this view. First, sensory characteristics that were consonant with the presence of energy (thickness and creaminess) enhanced the satiating effects of energy in the context of a drink ${ }^{(21)}$. Second, the sensory characteristics, but not protein content, of a snack preload altered subsequent selection of protein-rich foods ${ }^{(22)}$. The present study extends these findings to ask whether perceived thickness and creaminess imparted by addition of protein in a beverage may at least, in part, explain why protein-enriched foods and drinks are found to be more satiating than are other macronutrients in short-term tests of satiety.

A key driver for the present study was an earlier investigation in our laboratory that found that a drink preload

Abbreviations: $\mathrm{HC}+$, high-sensory carbohydrate; $\mathrm{HC}-$, high carbohydrate without added sensory quality; HP+, high-sensory protein; HP-, low-sensory protein; LE, low energy; SIPM, Sussex Ingestion Pattern Monitor.

*Corresponding author: M. R. Yeomans, fax +44 1273 678058, email martin@sussex.ac.uk 
containing $50 \%$ of additional energy as protein was more satiating than an isoenergetic drink enriched with carbohydrate only ${ }^{(23)}$. Indeed, in that study, there was no evidence of satiety, either through reduced intake at a test lunch or in altered appetite ratings after the consumption of the highenergy $(1250 \mathrm{~kJ})$ carbohydrate-enriched drink compared with the low-energy (LE, $327 \mathrm{~kJ}$ ) control drink. This finding is consistent with broader suggestions that energy consumed in beverage form generates weak satiety ${ }^{(24)}$. In the previous study, we attempted to disguise the nutritional differences between the two high-energy drinks; however, evaluations by participants clearly reported subtle sensory differences, with the high-protein drink rated as slightly creamier, slightly thicker in texture and less pleasant than the carbohydrate drink. Therefore, sensory differences may have contributed to the short-term satiating effects of the protein drink rather than simply post-ingestive effects. More recent studies suggest a key role for sensory characteristics in determining the satiating effects of beverages ${ }^{(21)}$.

The present study directly assessed the importance of sensory properties by contrasting the satiating effects of three isoenergetic high-energy drinks relative to a LE control. Two versions of the high-energy drinks were enriched with protein, but differed sensorially: one high-sensory protein $(\mathrm{HP}+)$ drink was created to taste slightly thicker and creamier than the other (HP-, low-sensory protein). The third highenergy drink ( $\mathrm{HC}+$, high-sensory carbohydrate) was enriched purely by carbohydrate and had its flavour adjusted to match that of the HP+ protein drink. Since the same high-carbohydrate formulation, in the absence of sensory cues, was not satiating in our previous study ${ }^{(23)}$, any evidence that the sensory-enhanced $\mathrm{HC}+$ drink resulted in satiety would be clear evidence that sensory characteristics, such as thicker texture and creamy flavour, may be a key element in the generation of satiety by nutrients in a beverage context. Thus, if the enhanced satiating effects of addition of protein are only a consequence of post-ingestive actions, the prediction would be that the HP- and HP+ drinks would have similar effects on subsequent rated appetite and intake at a test meal. In contrast, if protein-induced satiety is dependent on the sensory characteristics imparted by the added protein, then the two sensory-enhanced drinks ( $\mathrm{HP}+$ and $\mathrm{HC}+$ ) would be predicted to be more satiating than the high-protein low-sensory $(\mathrm{HP}-)$ drink. Thus, the present design provided a clear means of dissociating the potential roles of sensory and postingestive effects of the satiating effects of protein.

\section{Method \\ Design}

A repeated measures design contrasted satiety (changes in rated appetite and test lunch intake) following consumption of four preload drinks. Three preloads had a higher energy content, two with $44 \%$ of energy added as protein either with $(\mathrm{HP}+)$ or without $(\mathrm{HP}-)$ enhanced creaminess and thickness, and the third ( $\mathrm{HC}+$ ) had energy added as carbohydrate, but thickness and creaminess matched to the $\mathrm{HP}+$ condition. The fourth preload was a LE control.

\section{Participants}

Potential participants were recruited from participant databases held by the School of Psychology, University of Sussex, on the basis that they were participating in a study about mood and food. Inclusion criteria were young men aged 18-35 years and whose BMI was within the normal range $\left(18-25 \mathrm{~kg} / \mathrm{m}^{2}\right)$. Healthy normal-weight men were tested to minimise demand effects generated by the laboratory testing setting. Exclusion criteria included smoking more than five cigarettes per week; eating, metabolic or respiratory disorder; any athletes in training; and those having a restrained eating style defined as individuals scoring seven or more on the restraint scale score from the Three Factor Eating Questionnaire $^{(25)}$. Participants gave written informed consent, and the protocol was approved by the Sussex University Ethics Committee. Two participants failed to attend all sessions and their data were excluded. The twenty-six male participants who completed all sessions had a mean age of $21 \cdot 1$ (SD 2.3) years, a mean Three Factor Eating Questionnaire restraint of 2.7 (SD 2.4) and normal BMI of $21.9(\mathrm{SD} 1.6) \mathrm{kg} / \mathrm{m}^{2}$. Participants received $£ 40$ for participation.

\section{Test preload drinks}

Drinks were developed iteratively using taste tests with volunteers to create two high-protein drinks (HP+ and $\mathrm{HP}-$ ) with similar energy content, one resembling a juice drink and the other perceived by volunteers to be a creamy drink. The HC+ drink was developed to match the HP+ in terms of perceived thickness and creaminess, but with the additional energy added as carbohydrate only. The final prototype drinks were assessed by an untrained panel of ten male volunteers, who were provided with $20 \mathrm{ml}$ samples of each of the high-energy preloads served in $50 \mathrm{ml}$ containers covered in foil to obscure visual cues. They were instructed to take a sufficient mouthful to allow completion of a series of sensory ratings, and were provided with water to cleanse the palate between mouthfuls. Sensory evaluations were made using $100 \mathrm{~mm}$ pen and paper visual analogue scales. Ratings confirmed that the two high-energy highsensory drinks (HP+ and $\mathrm{HC}+)$ were significantly thicker $(F(1 \cdot 1,8 \cdot 8)=9 \cdot 74, P<0 \cdot 05)(\mathrm{HP}+: 73(\mathrm{sE} 6) ; \mathrm{HC}+: 72(\mathrm{sE} 5))$ and had higher 'dairy-like' characteristics $(F(1 \cdot 1,9 \cdot 1)=8 \cdot 16$, $P<0.05$ ) (HP+ : 59 (SE 8); HC+: 66 (sE 8)) than the HP- beverage (dairy: 32 (SE 9); thickness: 38 (SE 10)). HP+ and $\mathrm{HC}+$ also tended $(F(2,16)=2 \cdot 42$, NS) to be perceived as creamier (HP+ : 59 (sE 8); HC+ : 66 (sE 8)) than the HP- drink (32 (sE 9)). The overall pattern of data confirmed that $\mathrm{HP}+$ and $\mathrm{HC}+$ were reasonably well-matched on the sensory characteristics that we were interested in, and both were perceived as thicker and creamier than was HP-.

The composition of the preloads is summarised in Table 1, and all were prepared from a base of LE fruit-yoghurt drink (Apricot and Peach drink Danao ${ }^{\circledR}$, Danone). HP+ and 
Table 1. Final nutritional composition of the four test preloads

\begin{tabular}{|c|c|c|c|c|}
\hline & \multicolumn{4}{|c|}{ Preload } \\
\hline & LE & $\mathrm{HP}-$ & $\mathrm{HC}+$ & $\mathrm{HP}+$ \\
\hline \multicolumn{5}{|l|}{ Protein } \\
\hline g per 300 g serving & 1.6 & $32 \cdot 9$ & $9 \cdot 2$ & $32 \cdot 2$ \\
\hline Energy (\%) & 7.9 & $44 \cdot 1$ & $12 \cdot 8$ & 44.0 \\
\hline \multicolumn{5}{|l|}{ Carbohydrate } \\
\hline g per $300 \mathrm{~g}$ serving & $18 \cdot 5$ & 34.9 & $58 \cdot 2$ & 34.9 \\
\hline Energy (\%) & 88.6 & $46 \cdot 8$ & $80 \cdot 8$ & $48 \cdot 0$ \\
\hline \multicolumn{5}{|l|}{ Fat } \\
\hline g per 300 g serving & 0.2 & $2 \cdot 7$ & 0.5 & $2 \cdot 4$ \\
\hline Energy (\%) & 1.86 & 8.4 & 1.6 & 7.4 \\
\hline Total energy (kJ) & 350 & 1248 & 1205 & 1225 \\
\hline Fibre (g per $300 \mathrm{~g}$ serving) & 1.0 & $1 \cdot 8$ & $3 \cdot 0$ & $3 \cdot 0$ \\
\hline
\end{tabular}

LE, low energy; HP-, low-sensory protein; $\mathrm{HC}+$, high-sensory carbohydrate; $\mathrm{HP}+$, high-sensory protein.

$\mathrm{HP}$ - were developed to provide $44 \%$ of energy as protein and $\mathrm{HC}+$ contained $87 \%$ of added energy as carbohydrate and $13 \%$ as protein. Protein content was varied through use of different amounts of virtually fat-free fromage-frais (Waitrose brand) and a whey isolate (CMC Whey ${ }^{\circledR}$, Fast Research), which at the concentrations used had reduced bitterness compared with other whey sources and so was easier to disguise. Carbohydrate was added as a combination of maltodextrin (Cerostar) and sucrose. HP+ and $\mathrm{HC}+$ had added yoghurt and vanilla flavours (IFF) to enhance perceived creaminess and a small amount of guar gum (Meyprodor, a water-soluble fibre; Danisco) to enhance perceived thickness. The LE condition used the base drink diluted with water.

\section{Test meals}

Participants consumed a standardised breakfast in the laboratory on each test day, consisting of breakfast cereal (either crunchy-nut cornflakes or Special K cereal, both Kellogg's UK), orange juice and semi-skimmed milk (1710.2 kJ). The test lunch comprised ad libitum consumption of pasta (fusilli variety, Sainsbury's UK) mixed with commercial tomato-based herb sauce (Napoletana, Sainsbury's UK) and served in bowls at a ratio of $250 \mathrm{~g}$ cooked pasta to $250 \mathrm{~g}$ sauce. The test meal provided $500 \mathrm{~kJ}$ of energy $(3.7 \mathrm{~g}$ protein; $19.8 \mathrm{~g}$ carbohydrate and $1.5 \mathrm{~g}$ fat) per $100 \mathrm{~g}$.

\section{Assessment of rated appetite, mood and food intake at the test lunch}

Data were collected using the Sussex Ingestion Pattern Monitor (SIPM: University of Sussex), a computer-based Universal Eating Monitor ${ }^{(26)}$ for measuring food intake and recording rated appetite ${ }^{(27)}$. This ensured minimal monitoring or disturbance from the experimenter. SIPM consisted of a disguised electronic balance (Sartorius BP 4100-S, Sartorius) fitted into the desktop and connected to an Apple Macintosh G3 computer (Apple Computer, Inc.), with the balance surface obscured by a placemat. The system was custom programmed using FutureBasic (Staz Software) to read the balance weight on stability to $0 \cdot 1 \mathrm{~g}$ accuracy during the test meal. At the start of the lunch session, a $500 \mathrm{~g}$ plate of pasta was placed on the balance and the experimenter left the cubicle. The computer instructions were to 'Eat as much as you want'. A separate side plate was provided to place cutlery on when not eating so that the weight of cutlery did not interfere with weighing. The SIPM system prompted participants to call the experimenter for a refill after the sixth interruption to their meal, by which time 300-400 $\mathrm{g}$ had been consumed, which ensured that participants could not use an empty bowl as an external cue to end their meal. This process was repeated until the participants indicated that they had 'finished' their meal.

Before and after each preload and meal, participants completed computerised ratings of hunger, fullness, thirst, clear-headed, happy, friendly, jittery, nauseous, energetic and relaxed, presented in the form 'How $<$ descriptor $>$ do you feel?'. Mood ratings were included as distractors. Ratings were made by electronic visual analogue scales end-anchored with 'Not at all' (scored zero) and 'Extremely' (scored 100). Sensory and hedonic ratings (familiar, sweet, pleasant, sour, bitter, creamy, fruity, refreshing, thick, novel, dairy and fatty) of the preload were made using the same style of visual analogue scales when the drink was first tasted and once it had been consumed in full, and participants also rated the lunch when first tasted and at the end of the meal. Polarity of all computerised ratings was randomised to minimise carry-over effects.

\section{Procedure}

Participants were instructed to eat as normal on the day before testing, but consume only water from 23.00 hours the previous evening. On each test day, breakfast was served between 08.30 and 10.00 hours, and participants left the laboratory after breakfast before returning for their later appointments, but were restricted to drink water only during this period. A $500 \mathrm{ml}$ bottle of water was provided to encourage water consumption throughout the morning. To encourage compliance with instructions not to eat or drink anything other than water, participants were warned that random samples of saliva could be collected at any time during the study (this was not followed up). Participants returned to the laboratory $180 \mathrm{~min}$ after breakfast and consumed the relevant preload in a small, ventilated cubicle, where they also completed the mood and appetite ratings. Preloads were served in a $400 \mathrm{ml}$ polystyrene cup with an opaque lid and straw, and participants were instructed to consume the entire drink within $10 \mathrm{~min}$. To monitor compliance, each preload was weighed before and after consumption and preload session duration recorded. Once they had consumed the preload and completed the associated ratings, they rested in an adjacent waiting room until lunch, which was served $30 \mathrm{~min}$ after the preload session began. The delay between preload and lunch was selected based on an earlier study, where similar drinks had the same impact on subsequent appetite, regardless of whether they were consumed 30 or $120 \mathrm{~min}$ prior to the test meal ${ }^{(23)}$. Once they had consumed as much of the lunch as they wanted and had completed all ratings, they were free to leave, except on the final session, when 
they had a structured debriefing where they were asked about the purpose of the study. Participants were also asked if they had noticed differences between the preloads, breakfast or lunch meals across the test days and were asked: 'Have you ever tasted a high-protein shake - otherwise known as body building drinks?' to judge familiarity with products like the drinks under test.

\section{Data analysis}

Intake data were contrasted between the four preload conditions using one-way repeated measures ANOVA, with the prediction that all three higher-energy preloads would reduce intake but that $\mathrm{HP}+$ and $\mathrm{HC}+$ would have a larger effect than $\mathrm{HP}-$. Total energy intake was calculated as the sum of energy consumed at breakfast, preload and test meal, and these were contrasted using ANOVA. The degree of compensation at the ad libitum meal for the energy consumed in the preloads was calculated as the energy difference between each high-energy test preload and the LE, expressed as a fraction of the reduction ${ }^{(28,29)}$. Computer failure meant all rating data were lost for one participant on $1 \mathrm{~d}$, and initial analysis of changes in hunger after preload consumption identified one participant as a significant outlier (data more than two standard deviations from the mean) in two preload conditions and his data were excluded from further analysis. After confirming that there were no spurious baseline differences, changes in hunger and fullness immediately after consuming the preload and at the start of lunch were calculated and contrasted using two-way ANOVA. Similarly, sensory and hedonic ratings before and after preload consumption were contrasted between preloads to confirm that the expected sensory differences were evident and that these did not generate confounding differences in liking. Within-subjects contrasts were used to test specific predictions and Bonferonni post hoc corrections applied when making post hoc comparisons. Data were analysed using SPSS 18 for Macintosh (PASW Ltd).

\section{Results}

\section{Intake}

Lunch intake varied significantly between preload conditions $(F(3,75)=6 \cdot 26, P<0 \cdot 01$ : Fig. 1(a)), with intake following the two thicker and creamier drinks ( $\mathrm{HP}+$ and $\mathrm{HC}+$ ) significantly less than after the LE control $(P<0.01$ and $P<0.001$, respectively). Critically, intake after the thick/ creamy high-protein HP+ drink was significantly less than after the high-protein drink without thick/creamy sensory characteristics ( $\mathrm{HP}-, P<0.05)$, and intake after the HPdrink did not differ significantly from that after LE (Fig. 1(A)) Short-term total energy intake (Fig. 1(B)) also differed significantly between conditions $(F(3,75)=11 \cdot 13, P<0 \cdot 001)$, with significantly greater energy intake in all three high-energy conditions compared with LE, although total energy intake was significantly lower in the $\mathrm{HP}+$ than $\mathrm{HP}-$ condition $(F(1,25)=5.46, P<0.05)$. Overall compensation for preload energy was $22.4 \%$ in the $\mathrm{HP}-$ condition compared with $50 \cdot 2 \%$ in the HC+ and $52.6 \%$ in $\mathrm{HP}+$ conditions.

\section{Rated hunger and fullness}

Rated hunger and fullness immediately before preload consumption did not differ significantly between preload conditions (hunger: $F(3,72)=2 \cdot 23$, NS; fullness: $F(3,72)$ $=2 \cdot 48$, NS). As expected, changes in hunger depended on time of rating $(F(1,72)=14.07, P<0 \cdot 001)$, with a larger initial decrease in hunger immediately after preload consumption and some recovery of hunger by the lunch test. There was a trend for a significant overall effect of preload $(F(3,72)=2 \cdot 67, P=0 \cdot 056)$, but the interaction between time and preload was not significant $(F(3,72)=0 \cdot 86$, NS). As can be seen (Table 2), hunger decreased immediately after consuming all four preloads, but this decrease was only sustained in the $\mathrm{HP}+$ and $\mathrm{HC}+$ conditions. The decrease in hunger in both the $\mathrm{HP}+$ and $\mathrm{HC}+$ conditions immediately before
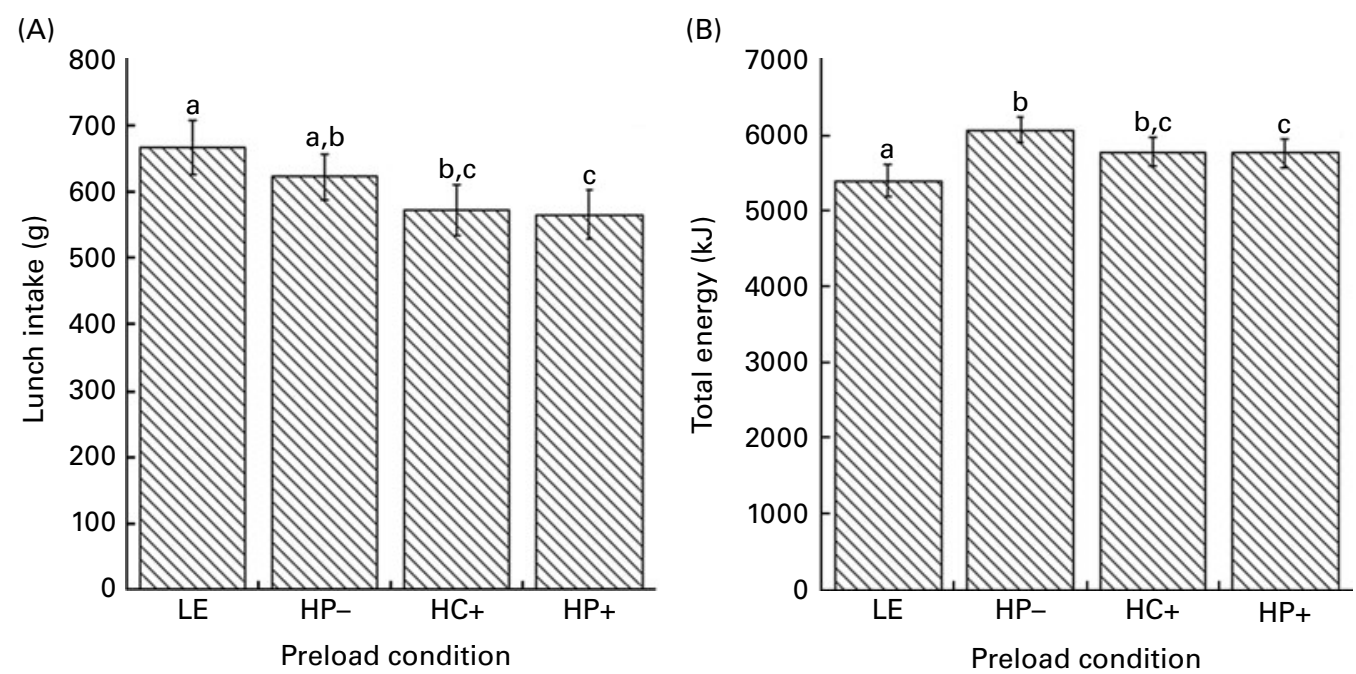

Fig. 1. (A) Test food intake at lunch and (B) total energy consumed in the laboratory tests in the four preload conditions: low energy (LE), low-sensory protein $(\mathrm{HP}-)$, high-sensory carbohydrate $(\mathrm{HC}+)$ and high-sensory protein $(\mathrm{HP}+)$. Values are means, with their standard errors represented by vertical bars, $n 26$. a,b,c Mean values with unlike letters were significantly different $(P<0.05$ or higher $)$. 
Table 2. Changes in hunger, fullness, thirst and nausea immediately and $30 \mathrm{~min}$ after consuming the four test preload drinks (Mean values with their standard errors)

\begin{tabular}{|c|c|c|c|c|c|c|c|c|c|}
\hline \multirow{3}{*}{$\begin{array}{l}\text { Attribute } \\
\text { rated }\end{array}$} & \multirow{3}{*}{$\begin{array}{c}\text { Time } \\
\text { after preload } \\
\text { ingestion (min) }\end{array}$} & \multicolumn{8}{|c|}{ Preload condition } \\
\hline & & \multicolumn{2}{|c|}{ LE } & \multicolumn{2}{|c|}{$\mathrm{HP}-$} & \multicolumn{2}{|c|}{$\mathrm{HC}+$} & \multicolumn{2}{|c|}{$\mathrm{HP}+$} \\
\hline & & Mean & SE & Mean & SE & Mean & SE & Mean & SE \\
\hline \multirow[t]{2}{*}{ Hunger } & 0 & $-9^{a}$ & 3 & $-10^{\mathrm{a}}$ & 2 & $-14^{a}$ & 4 & $-17^{\mathrm{a}}$ & 4 \\
\hline & 30 & $-2^{a}$ & 2 & $-4^{a, b}$ & 3 & $-8^{b}$ & 3 & $-10^{b}$ & 3 \\
\hline \multirow[t]{2}{*}{ Fullness } & 0 & $8^{a}$ & 3 & $26^{\mathrm{b}}$ & 4 & $12^{a}$ & 3 & $14^{a}$ & 3 \\
\hline & 30 & $0^{a}$ & 2 & $7^{\mathrm{a}, \mathrm{b}}$ & 2 & $12^{\mathrm{b}}$ & 3 & $15^{\mathrm{b}}$ & 3 \\
\hline \multirow[t]{2}{*}{ Thirst } & 0 & $-22^{a}$ & 5 & $-19^{a}$ & 6 & $-14^{a, b}$ & 6 & $-9^{b}$ & 6 \\
\hline & 30 & $-6^{a}$ & 3 & $-16^{b}$ & 5 & $-6^{a}$ & 4 & $-11^{\mathrm{b}}$ & 5 \\
\hline \multirow[t]{2}{*}{ Nausea } & 0 & $-2^{a}$ & 4 & $2^{a}$ & 4 & $3^{a}$ & 4 & $2^{a}$ & 3 \\
\hline & 30 & $-1^{a}$ & 3 & $-2^{a}$ & 4 & $-4^{a}$ & 3 & $-2^{a}$ & 4 \\
\hline
\end{tabular}

$\mathrm{LE}$, low energy; $\mathrm{HP}-$, low-sensory protein; $\mathrm{HC}+$, high-sensory carbohydrate; $\mathrm{HP}+$, high-sensory protein.

${ }^{\mathrm{a}, \mathrm{b}}$ Mean values within a row with unlike superscript letters were significantly different $(P<0.05$ or less using Bonferroni-protected contrasts).

lunch was significantly greater than that in the LE control condition (both $P<0.05$ ), with changes after $\mathrm{HP}-$ being intermediate and not significantly different from other preloads. A similar pattern was seen with fullness ratings (Table 2), and here the effects of time $(F(1,72)=14 \cdot 87, P<0.001)$, preload $(F(2,72)=8.37, P<0.001)$ and the preload $\times$ time interaction $(F(3,72)=3.09, \quad P<0.05)$ were all significant. Rated fullness increased in all four conditions immediately after consuming the drinks, although this increase was significantly greater in the $\mathrm{HC}+$ than in the other three conditions (LE, $P<0 \cdot 001$; HP,$- P<0.05$; HP+, $P<0 \cdot 01$ ). However, the initial increase in fullness was not sustained in the LE condition, and immediately before lunch, the largest increases in fullness were seen in the HP+ and $\mathrm{HC}+$ conditions.

\section{Rated thirst and nausea}

Protein-elicited thirst presented a possible confound for interpretation of the present study (Table 2). As baseline values did not differ significantly between conditions, change data were used to contrast effects of preloads. Thirst varied with time $(F(1,72)=6.88, P<0.05)$, with the expected large decrease immediately after drink consumption; however, although the main effect of preload condition was not significant $(F(3,72)=1 \cdot 33$, NS), there was a significant interaction between preload and time $(F(3,72)=3 \cdot 22$, $P<0.05)$. Surprisingly, thirst was reduced more after the two high-protein preloads relative to the LE control and $\mathrm{HC}+$ preloads prior to lunch.

Differences in lunch intake could also have been confounded by any gastric discomfort from consuming these drinks. However, if so, then we would have expected differences in nausea ratings between preloads; however, there was no significant difference in baseline nausea $(F(3,72)=1.66$, NS), and no significant effects of preload $(F(3,72)=0 \cdot 29, \quad$ NS), time $(F(1,72)=1 \cdot 43$, NS $)$ or time $\times$ preload interaction $(F(3,72)=2 \cdot 39$, NS) for changes in nausea immediately and $30 \mathrm{~min}$ after preload ingestion were observed.

\section{Sensory and hedonic ratings of the test meal and preloads}

To assess whether the sensory differences evident during pilot work were detectable during the satiety tests, evaluations of the four preloads at the start and end of ingestion were examined. To allow comparisons between pilot and test data, only ratings at the initial taste test are shown (Table 3). As expected, preloads differed significantly in perceived creaminess $(F(3,75)=37 \cdot 00, P<0 \cdot 001)$, thickness $(F(3,75)=23.82, \quad P<0.001), \quad$ fattiness, $\quad(F(3,75)=16.39$, $P<0.001)$ and perceptions of dairy $(F(3,75)=17 \cdot 01$, $P<0.001)$. HP - was rated as significantly less thick and less fatty than were the $\mathrm{HP}+$ and $\mathrm{HC}+$, but (in contrast to pilot data) was rated similarly on creaminess and dairylike characteristics. Sensory ratings did not differ between the start and end of preload ingestion, with only one significant interaction arising from evaluation of ratings of the 'dairy-like' characteristics $(F(2 \cdot 0,47 \cdot 6)=2 \cdot 80, P<0 \cdot 05)$, although within-subjects contrasts did not identify the cause of that interaction, which may be spurious. The drinks did not differ significantly in sweetness $(F(3,75)=1 \cdot 10$, NS),

Table 3. Sensory and hedonic evaluations of the preloads at the initial taste test

(Mean values with their standard errors)

\begin{tabular}{|c|c|c|c|c|c|c|c|c|}
\hline \multirow{3}{*}{$\begin{array}{l}\text { Rating } \\
\text { made }\end{array}$} & \multicolumn{8}{|c|}{ Preload condition } \\
\hline & \multicolumn{2}{|c|}{ LE } & \multicolumn{2}{|c|}{$\mathrm{HP}-$} & \multicolumn{2}{|c|}{$\mathrm{HC}+$} & \multicolumn{2}{|c|}{$\mathrm{HP}+$} \\
\hline & Mean & $\mathrm{SE}$ & Mean & $\mathrm{SE}$ & Mean & SE & Mean & SE \\
\hline Sweet & 68 & 2 & 72 & 3 & 76 & 2 & 68 & 4 \\
\hline Thick & $27^{\mathrm{a}}$ & 4 & $61^{\mathrm{b}}$ & 5 & $77^{\mathrm{c}}$ & 3 & $77^{\mathrm{c}}$ & 4 \\
\hline Creamy & $32^{\mathrm{a}}$ & 4 & $63^{b}$ & 3 & $72^{b}$ & 3 & $69^{b}$ & 4 \\
\hline Fatty & $31^{a}$ & 4 & $45^{a, b}$ & 4 & $50^{\mathrm{b}}$ & 4 & $53^{b}$ & 4 \\
\hline Novel & 39 & 4 & 46 & 5 & 46 & 5 & 51 & 5 \\
\hline Bitter & 30 & 4 & 28 & 4 & 28 & 4 & 26 & 3 \\
\hline Dairy & $31^{a}$ & 5 & $61^{\mathrm{b}}$ & 3 & $58^{\mathrm{b}}$ & 5 & $68^{\mathrm{b}}$ & 4 \\
\hline
\end{tabular}

$\mathrm{LE}$, low energy; HP-, low-sensory protein; $\mathrm{HC}+$, high-sensory carbohydrate; $\mathrm{HP}+$, high-sensory protein.

$a, b, c$ Mean values with unlike superscript letters were significantly different for ratings which differed between conditions (thick, creamy and dairy) $(P<0.05$ or less using Bonferroni-protected contrasts). 


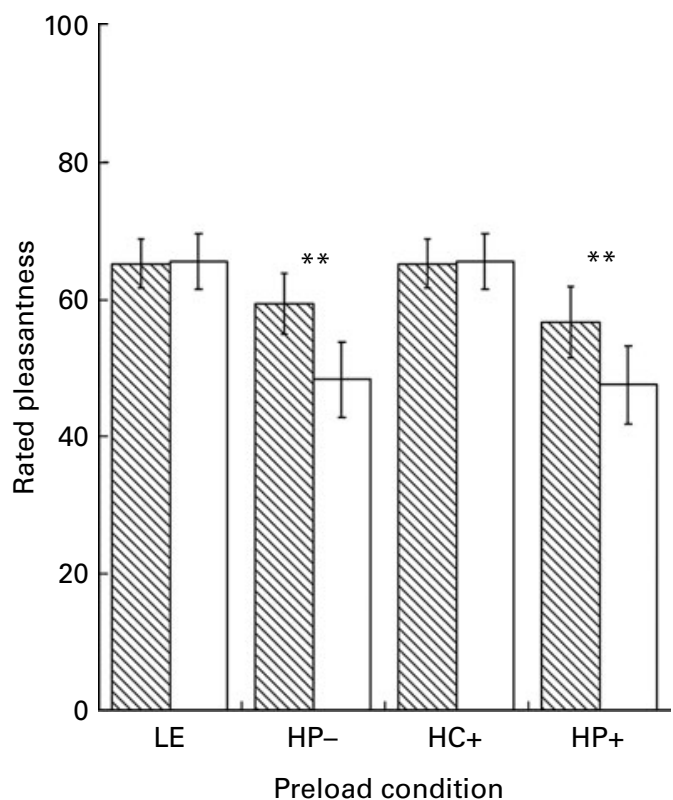

Fig. 2. Rated pleasantness of the four test drinks before (start, $\Sigma$ ) and after (end, ㄷ) they had been consumed: low energy (LE), low-sensory protein $(\mathrm{HP}-)$, high-sensory carbohydrate $(\mathrm{HC}+)$ and high-sensory protein $(\mathrm{HP}+)$. Values are means, with their standard errors represented by vertical bars, $n 26$. ${ }^{* *}$ Mean value was significantly different between start and end ratings $(P<0.01)$.

bitterness $(F(3,75)=0 \cdot 47$, NS) or novelty $(F(3,75)=1 \cdot 93$, NS). As expected, rated novelty declined significantly between the start and end of ingestion $(F(1,25)=10 \cdot 48, P<0 \cdot 01)$.

There were no overall significant differences in rated pleasantness of the four preloads $(F(3,75)=2 \cdot 70$, NS), but there was a significant interaction between preload and rating time $(F(3,75)=6.27, \quad P<0.001)$. Ratings before ingestion did not differ significantly between conditions $(F(3,75)=0 \cdot 86$, NS). However, pleasantness decreased significantly for the $\mathrm{HP}+$ and $\mathrm{HP}-$ preloads, but did not change in $\mathrm{HC}+$ or $\mathrm{LE}$ conditions (Fig. 2).

There were no significant differences in overall rated pleasantness of the pasta between conditions $(F(3,75)=1.92$, NS), nor any interaction between preload and taste $(F(2 \cdot 4,59 \cdot 7)=1 \cdot 59$, NS). Rated pleasantness of the pasta declined significantly from start to end of the meal in all conditions $(F(1,25)=26 \cdot 60, P<0 \cdot 001)$.

\section{Participant awareness}

The majority of participants (20/26) believed that the experiment was investigating 'food and mood', in line with the explanation provided during recruitment. In all, two participants correctly identified: 'effects of the drink upon appetite/the meal'. A total of ten participants correctly said they received different drinks each test day, while nine participants recalled noticing only two different drinks. Overall, these responses indicate that many participants were not overtly aware of the purpose of the experiment. None of the participants reported regular consumption of commercially available protein drinks

\section{Discussion}

In the present study, the addition of protein to a beverage only resulted in short-term satiety when the addition of protein was combined with small increases in thickness and creamy flavour. Thus the sensory-enhanced HP+ drink was more satiating than the same level of protein added in the absence of sensory cues $(\mathrm{HP}-)$. Moreover, whereas the addition of extra energy purely as carbohydrate was previously found to be ineffective at generating satiety in this context ${ }^{(23)}$, when the same carbohydrate was added alongside increased creamy flavour and thickness (the $\mathrm{HC}+$ preload), the drink was as satiating as the HP+ drink. Together, both the difference in satiety response between protein drinks, which differed in sensory characteristics, and similarity of response to drinks that were perceived as similarly thick and creamy, but which differed in macronutrient content (HP+ and $\mathrm{HC}+$ ), suggest that the sensory characteristics of beverages are critical in determining short-term satiety.

The key question is what explains the difference in satiety between $\mathrm{HP}+$ and $\mathrm{HP}-$ conditions. This effect cannot easily be attributed to nutritional differences, as these preloads had similar amounts of added protein, both chiefly through different extracted versions of whey protein. Many studies suggest that whey protein is more satiating than other forms of protein, based on both greater compensatory eating responses ${ }^{(30)}$, greater suppression of rated appetite ${ }^{(17,31)}$ and increased release of satiety hormones ${ }^{(17,31)}$ after consuming preloads enriched in whey protein, although some studies failed to confirm whey as more satiating than other protein sources $^{(16)}$. However, as HP+ and HP- had similar levels of whey protein, it is difficult to attribute the difference in effects on appetite to small differences in the type of protein. A more consistent finding in the literature is that preloads enriched with carbohydrate are less satiating than are energy-matched protein preloads $(2,4,23,32,33)$. Thus, the prediction, based on nutrient composition, would be that the $\mathrm{HC}+$ preload would have been less satiating than the HP+ preload. The finding that altering the thickness and creamy flavour of the $\mathrm{HC}+$ preload to make it more similar to the $\mathrm{HP}+$ preload resulted in similar satiety responses to the two drinks implies that may be sensory rather than macronutrient differences are critical in determining different short-term satiety responses between carbohydrate and protein-enriched beverages. This finding fits well with a recent study in our laboratory, which also found that making drinks thicker in texture and creamier in flavour enhanced the degree to which added protein was satiating ${ }^{(21)}$. In relation to the present study, the $\mathrm{HC}+$ drink was more satiating than a similar carbohydrate drink without added thickness or creaminess in an earlier study $^{(23)}$. It would have been useful to have included this HC- (the high carbohydrate without added sensory quality) drink in the present study. However, conditions equivalent to the $\mathrm{HC}+/ \mathrm{HC}-$ contrasts were included in our recent study $^{(21)}$, and again altering thickness and creamy flavour enhanced satiety.

How then might altering the thickness and creaminess of a drink enhance the satiating efficiency of ingested nutrients? 
In line with recent ideas about sensory-nutrient interactions in satiety ${ }^{(34)}$, we hypothesised that products with higher protein content, particularly in a dairy context, have some sensory characteristics in common, including both a thicker texture and creamy flavour. Past experience of both these sensory characteristics and consequent effects of ingestion on appetite of such products should lead to an expectation that drinks with these sensory characteristics would be more filling, thereby facilitating the consumer to respond to actual nutrient ingestion. Several lines of evidence support this suggestion. First, differences in the profile of release of satiety hormones have been shown between protein and carbohydrate preloads ${ }^{(16,35)}$. Many of these studies do not report the sensory analysis of the preloads, but it is likely that subtle sensory differences would have existed. It is established that orosensory cues can solicit release of hormones related to appetite control $^{(36,37)}$, probably as part of learned preparatory responses that prepare the body to process nutrients ${ }^{(38)}$. Thus, subtle sensory differences between beverages, such as in thickness and creaminess, could modify post-ingestive processing of nutrients by facilitating anticipatory hormone release. Sensory cues also generate explicit expectations about how satiating foods will be ${ }^{(39)}$, and recent data from our laboratory confirm that the subtle differences in sensory characteristics between preloads in the present study would have resulted in explicit expectations of satiety ${ }^{(40)}$. This interpretation of the differences in response to the three high-energy preloads in the present study relies on subtle sensory differences between stimuli. The analysis of participants' evaluations of the drinks during testing suggests which of these sensory features were most important, but it is possible that preloads varied on other dimensions that were not captured by the evaluations used here. $\mathrm{HP}+$ and $\mathrm{HP}-$ preloads differed significantly in rated thickness only, with non-significant trends for greater creaminess, fattiness and dairy-like qualities. Although there was a trend for higher creaminess in both $\mathrm{HP}+$ and $\mathrm{HC}+$ conditions relative to $\mathrm{HP}-$, all of these were rated as creamier than was the control. Differences between high-energy conditions were less clear in the main study than in the pilot studies, possibly due to contrast effects making this more evident when products were rated alongside each other in the absence of the LE condition, an effect that we have seen in other studies ${ }^{(21)}$ and which fits with more general contrast effects in sensory evaluation ${ }^{(41)}$. Importantly, $\mathrm{HC}+$ and $\mathrm{HP}+$ appeared well-matched in terms of thickness and creaminess, with only a trend for HC+ having less dairy-like qualities than $\mathrm{HP}+$. The finding that perceived thickness was important fits with other studies that suggest that this characteristic is an important orosensory satiety cue ${ }^{(42-44)}$. Studies also suggest that viscosity is an important component of the satiating efficiency of beverages, with greater satiety from more viscous drinks ${ }^{(45-48)}$, and texture appearing to be more important than flavour in determining satiation in a dairy context ${ }^{(49)}$. The present literature implies that textural differences, probably viscosity, may be the most likely explanation for why $\mathrm{HC}+$ was more satiating here than would be expected based on nutrient content alone and why $\mathrm{HP}-$ was less satiating than $\mathrm{HP}+$.
An alternative explanation for differences between preloads, however, could be the small differences in soluble fibre content generated by the use of guar gum as thickening agent. Increased viscosity generated by the addition of insoluble fibres has been shown to enhance satiety ${ }^{(50,51)}$, increase release of satiety-related gastric hormones ${ }^{(52)}$ and modify gastric emptying ${ }^{(53)}$. In all of these studies, differences in post-ingestive effects of fibre were confounded by likely differences in sensory characteristics through changed viscosity, and the present literature does not allow easy separation of orosensory and post-ingestive effects. However, it has been suggested that the dilution effects of small amounts of added fibre on viscosity in the stomach make orosensory explanations more likely ${ }^{(54)}$. Most studies exploring effects of fibre use much greater quantities than was used to subtly thicken $\mathrm{HP}+$ and $\mathrm{HC}+$ : for example $12 \mathrm{~g}$ of guar gum was added to explore effects on gastric emptying ${ }^{(53)}$ and enhanced satiety was reported after addition of $12 \mathrm{~g}$ of inulin in a protein-rich beverage ${ }^{(55)}$, compared with $1.2 \mathrm{~g}$ guar gum used here. No study that we are aware of has demonstrated enhanced satiety or physiological response to such small quantities; however, the only way to truly isolate sensory $v$. post-ingestive effects would be to contrast the same preloads when infused into the stomach to see whether the apparent sensory/nutrient interactions suggested here persist in the absence of orosensory cues. However, past research suggests that orosensory cues are necessary for the full expression of satiety, with reduced satiety when the same foods are infused into the stomach or intestine than when ingested ${ }^{(19)}$, and although a nutrient effect of the added guar gum or very small differences in fat content between preload cannot be excluded, such explanations are less plausible than would be effects through sensory-nutrient interactions.

In the present study, there was a relatively short delay between beverage consumption and the test meal (minimum of $20 \mathrm{~min}$ ), and this may have exaggerated the effects of sensory quality and reduced the impact of post-ingestive satiety cues. However, the delay we used was chosen since an earlier study found no difference in effect of protein preloads between 30 and 120 min delays ${ }^{(23)}$, and other preload studies suggest that short delays are most effective ${ }^{(28)}$. However, it may be that some participants treated the drink as a course of the test meal, implying that the responses were more related to satiation than satiety.

We did find a decrease in the rated pleasantness of the preload after ingestion in both protein conditions, but not in the $\mathrm{HC}+$ or control conditions. This finding is consistent with previous research suggesting that protein foods produce greater sensory-specific satiety than do other macronutrients ${ }^{(56)}$, although sensory-specific satiety effects did not emerge in previous experiments in our laboratory ${ }^{(1,23)}$. This difference between protein and non-protein preloads cannot readily explain the differences in intake and appetite at the test lunch, since intake and appetite after $\mathrm{HC}+$ and $\mathrm{HP}+$ preloads were similar and significantly different from those after HP-.

Overall, the critical finding in the present study was that matching high-protein and carbohydrate preloads in terms of perceived thickness and creaminess resulted in very similar 
satiety responses to these drinks, whereas, normally, protein has been found to be more satiating than carbohydrate. In contrast, there were significant differences in satiety following consumption of protein preloads that were matched in nutritional content but which differed in thickness and creaminess, with the less thick and creamy version ( $\mathrm{HP}-$ ) less satiating. These findings have implications both for the future conduct of human preload studies, where greater care is needed to match stimuli at a sensory level and in terms of our understanding of the nature of satiety. In particular, differences in the satiating effects of different types of foods, such as liquid $v$. solid etc, may be, in part, attributed to the role of sensory cues in facilitating post-ingestive satiety.

\section{Acknowledgements}

The reported study was conducted as part of a DPhil thesis funded by Danone Research. None of the authors has any conflict of interest. E. J. B. conducted the study as part of her DPhil thesis, conducted the primary analyses and drafted the initial methods and results for this manuscript. A. L. provided advice on study design, technical support for the formulation of the test drink preloads and provided some of the test ingredients. M. R. Y. supervised the project, and had primary responsibility for production of the final manuscript and the analysis of rating data.

\section{References}

1. Bertenshaw EJ, Lluch A \& Yeomans MR (2009) Dosedependent effects of beverage protein content upon short-term intake. Appetite 52, 580-587.

2. Barkeling B, Rossner S \& Bjorvell H (1990) Effects of a highprotein meal (meat) and a high-carbohydrate meal (vegetarian) on satiety measured by automated computerized monitoring of subsequent food-intake, motivation to eat and food preferences. Int J Obes 14, 743-751.

3. Johnson J \& Vickers Z (1993) Effects of flavor and macronutrient composition of food servings on liking, hunger and subsequent intake. Appetite 21, 25-39.

4. Hill AJ \& Blundell JE (1986) Macronutrients and satiety: the effects of a high-protein or high-carbohydrate meal on subjective motivation to eat and food preferences. Nutr Behav $\mathbf{3}$, 133-144.

5. Poppitt SD, Proctor J, McGill AT, et al. (2011) Low-dose whey protein-enriched water beverages alter satiety in a study of overweight women. Appetite 56, 456-464.

6. Akhavan T, Luhovyy BL \& Anderson GH (2011) Effect of drinking compared with eating sugars or whey protein on short-term appetite and food intake. Int J Obes (Lond) 35 , 562-569.

7. Astbury NM, Stevenson EJ, Morris P, et al. (2010) Doseresponse effect of a whey protein preload on within-day energy intake in lean subjects. Br J Nutr 104, 1858-1867.

8. Porrini M, Santangelo A, Crovetti R, et al. (1997) Weight, protein, fat and timing of preloads affect food intake. Physiol Behav 62, 563-570.

9. Stubbs RJ, van Wyk MC, Johnstone AM, et al. (1996) Breakfasts high in protein, fat or carbohydrate: effect on withinday appetite and energy balance. Eur J Clin Nutr 50, 409-417.
10. Latner JD \& Schwartz M (1999) The effects of a highcarbohydrate, high-protein or balanced lunch upon later food intake and hunger ratings. Appetite 33, 119-128.

11. Westerterp-Plantenga MS, Nieuwenhuizen A, Tome D, et al. (2009) Dietary protein, weight loss, and weight maintenance. Annu Rev Nutr 29, 21-41.

12. Lejeune MP, Kovacs EM \& Westerterp-Plantenga MS (2005) Additional protein intake limits weight regain after weight loss in humans. Br J Nutr 93, 281-289.

13. Leidy HJ, Tang M, Armstrong CL, et al. (2011) The effects of consuming frequent, higher protein meals on appetite and satiety during weight loss in overweight/obese men. Obesity (Silver Spring) 19, 818-824.

14. Weigle DS, Breen PA, Matthys CC, et al. (2005) A highprotein diet induces sustained reductions in appetite, ad libitum caloric intake, and body weight despite compensatory changes in diurnal plasma leptin and ghrelin concentrations. Am J Clin Nutr 82, 41-48.

15. Batterham RL, Heffron H, Kapoor S, et al. (2006) Critical role for peptide $\mathrm{YY}$ in protein-mediated satiation and bodyweight regulation. Cell Metab 4, 223-233.

16. Bowen J, Noakes M, Trenerry C, et al. (2006) Energy intake, ghrelin, and cholecystokinin after different carbohydrate and protein preloads in overweight men. J Clin Endocrinol Metab 91, 1477-1483.

17. Hall WL, Millward DJ, Long SJ, et al. (2003) Casein and whey exert different effects on plasma amino acid profiles, gastrointestinal hormone secretion and appetite. Br J Nutr 89, 239-248.

18. Veldhorst M, Smeets A, Soenen S, et al. (2008) Proteininduced satiety: effects and mechanisms of different proteins. Physiol Behav 94, 300-307.

19. Cecil JE, Francis J \& Read NW (1998) Relative contributions of intestinal, gastric, oro-sensory influences and information to changes in appetite induced by the same liquid meal. Appetite 31, 377-390.

20. Blundell JE \& Tremblay A (1995) Appetite control and energy (fuel) balance. Nutr Res Rev 8, 225-242.

21. Yeomans MR \& Chambers LC (2011) Satiety-relevant sensory qualities enhance the satiating effects of mixed carbohydrate-protein preloads. Am J Clin Nutr $\mathbf{9 4}$ 1410-1417.

22. Griffioen-Roose S, Mars M, Finlayson G, et al. (2011) The effect of within-meal protein content and taste on subsequent food choice and satiety. Br J Nutr 106, 779-788.

23. Bertenshaw EJ, Lluch A \& Yeomans MR (2008) Satiating effects of protein but not carbohydrate consumed in a between meal beverage context. Physiol Behav 93, 427-436.

24. Mattes R (2006) Fluid calories and energy balance: the good, the bad, and the uncertain. Physiol Behav 89, 66-70.

25. Stunkard AJ \& Messick S (1985) The three-factor eating questionnaire to measure dietary restraint, disinhibition and hunger. J Psychosom Res 29, 71-83.

26. Kissileff HR, Kilngsberg G \& Van Italie TB (1980) Universal eating monitor for continuous recording of solid or liquid consumption in man. Am J Physiol 238, R14-R22.

27. Yeomans MR (2000) Rating changes over the course of meals: what do they tell us about motivation to eat? Neurosci Biobehav Rev 24, 249-259.

28. Rolls BJ, Kim S, McNelis AL, et al. (1991) Time course of effects of preloads high in fat or carbohydrate on foodintake and hunger ratings in humans. Am J Physiol 260 R756-R763.

29. Shide D, Cabellero B, Reidelgerger R, et al. (1995) Accurate energy compensation for intragastric and oral nutrients in lean males. Am J Clin Nutr 61, 754-764. 
30. Anderson GH, Tecimer SN, Shah D, et al. (2004) Protein source, quantity, and time of consumption determine the effects of proteins on short-term food intake in young men. J Nutr 134, 3011-3015.

31. Veldhorst MA, Nieuwenhuizen AG, Hochstenbach-Waelen A, et al. (2009) Dose-dependent satiating effect of whey relative to casein or soy. Physiol Behav 96, 675-682.

32. Marmonier C, Chapelot D \& Louis-Sylvestre J (2000) Effects of macronutrient content and energy density of snacks consumed in a satiety state on the onset of the next meal. Appetite 34, 161-168.

33. Booth DA, Chase A \& Campbell AT (1970) Relative effectiveness of protein in the late stages of appetite suppression in man. Physiol Behav 5, 1299-1302.

34. de Graaf C (2011) Why liquid energy results in overconsumption. Proc Nutr Soc 70, 162-170.

35. de Graaf C, Blom WA, Smeets PA, et al. (2004) Biomarkers of satiation and satiety. Am J Clin Nutr 79, 946-961.

36. Teff K (2006) Learning hunger: conditioned anticipatory ghrelin responses in energy homeostasis. Endocrinology 147, 20-22.

37. Teff KL (2010) Cephalic phase pancreatic polypeptide responses to liquid and solid stimuli in humans. Physiol Behav 99, 317-323.

38. Woods SC (1991) The eating paradox: how we tolerate food Psychol Rev 98, 488-505.

39. Brunstrom JM (2011) The control of meal size in human subjects: a role for expected satiety, expected satiation and premeal planning. Proc Nutr Soc 70, 155-161.

40. McCrickerd K, Chambers L, Brunstrom JM, et al. (2012) Subtle changes in the flavour and texture of a drink enhance expectations of satiety. Flavour 1, 20 (epublication 31 October 2012).

41. Riskey DR, Parducci A \& Beauchamp GK (1979) Effects of context in judgements of sweetness and pleasantness. Percept Psychophys 26, 171-176.

42. Mattes RD \& Rothacker D (2001) Beverage viscosity is inversely related to postprandial hunger in humans. Physiol Behav 74, 551-557.

43. Martens MJ, Lemmens SG, Born JM, et al. (2011) A solid high-protein meal evokes stronger hunger suppression than a liquefied high-protein meal. Obesity (Silver Spring) 19, 522-527.
44. Russell K \& Delahunty C (2004) The effect of viscosity and volume on pleasantness and satiating power of rice milk. Food Qual Prefer 15, 743-750.

45. Juvonen KR, Purhonen AK, Salmenkallio-Marttila M, et al. (2009) Viscosity of oat bran-enriched beverages influences gastrointestinal hormonal responses in healthy humans. J Nutr 139, 461-466.

46. Lyly M, Ohls N, Lahteenmaki L, et al. (2010) The effect of fibre amount, energy level and viscosity of beverages containing oat fibre supplement on perceived satiety. Food Nutr Res 54 (epublication 14 April 2010).

47. Marciani L, Gowland PA, Spiller RC, et al. (2001) Effect of meal viscosity and nutrients on satiety, intragastric dilution, and emptying assessed by MRI. Am J Physiol Gastrointest Liver Physiol 280, G1227-G1233.

48. Zijlstra N, Mars M, de Wijk RA, et al. (2008) The effect of viscosity on ad libitum food intake. Int J Obes 32, 676-683.

49. Hogenkamp PS, Stafleu A, Mars M, et al. (2011) Texture, not flavor, determines expected satiation of dairy products. Appetite 57, 635-641.

50. Slavin J \& Green H (2007) Dietary fibre and satiety. Nutr Bull 32, S32-S42.

51. Wanders AJ, van den Borne JJGC, de Graaf C, et al. (2011) Effects of dietary fibre on subjective appetite, energy intake and body weight: a systematic review of randomized controlled trials. Obes Rev 12, 724-739.

52. Zijlstra N, Mars M, de Wijk RA, et al. (2009) Effect of viscosity on appetite and gastro-intestinal hormones. Physiol Behav 97, 68-75.

53. French SJ \& Read NW (1994) Effect of guar gum on hunger and satiety after meals of differing fat content: relationship with gastric emptying. Am J Clin Nutr 59, 87-91.

54. Marciani L, Gowland PA, Spiller RC, et al. (2000) Gastric response to increased meal viscosity assessed by echoplanar magnetic resonance imaging in humans. J Nutr 130, 122-127.

55. Perrigue MM, Monsivais P \& Drewnowski A (2009) Added soluble fiber enhances the satiating power of low-energydensity liquid yogurts. J Am Diet Assoc 109, 1862-1868.

56. Vandewater K \& Vickers Z (1996) Higher-protein foods produce greater sensory-specific satiety. Physiol Behav 59, $579-583$. 